\title{
The genus Navigiolum (Bacillariophyceae) in Mediterranean and North African rock pool habitats: description of four new species from Algeria
}

\author{
Horst Lange-Bertalot ${ }^{1}$, Bruno Fumanti ${ }^{2}$, Paolo Cavacini \& Nadia Tagliaventi ${ }^{2}$ \\ ${ }^{1}$ Institute for Ecology, Evolution and Diversity J.W. Goethe-University, Frankfurt a.M., Germany \\ ${ }^{2}$ Plant Biology Department, "Sapienza” University, Roma, Italy
}

\begin{abstract}
Four new species of the recently established genus Navigiolum (Naviculaceae, Bacillariophyceae) are described from samples collected in ephemeral rock pools of Algeria (North Africa). These species are compared with three similar taxa, recently described from comparable habitats in Sardinia (Italy). With a single exception, Navigiolum is currently composed of species that can be considered endemic elements of the circum-mediterranean region and of unusual autecology. They are living in small freshwater pools that are subject to extreme fluctuation. The seven populations and several more from Sardinia and Algeria appear closely related under light microscopy but can be clearly distinguished in the scanning electron microscope. Four new species, Navigiolum marvanii, $N$. algeriense, $N$. simplex and $N$. densistriatum are proposed.
\end{abstract}

Key words: Algeria, Bacillariophyceae, biogeography, diatoms, endemic, Navigiolum, new species, rock pools, Sardinia

\section{Introduction}

The genus Navigiolum is based on the typus generis N. spinosissimum LANGE-BerTALOT, Cavacini, Tagliaventi et Alfinito. The type species and the two other concomitantly described new species (LANGE-BERTALOT et al. 2003) originate from temporary water bodies, rock pools on basalt of central Sardinia, the second largest island in the Mediterranean Sea. Several other different specimens, obviously also belonging to Navigiolum, were found associated with them in the Sardinian "Paulis".

Navigiolum possesses the main characters of naviculoid diatoms which were formerly grouped under Navicula sensu lato. Over recent years Navicula sensu lato has been subdivided into Navicula sensu stricto and about thirty other genera. The combination of morphological features seen in Navigiolum does not fit any other previously established genus. One of the features of Navigiolum is the ability to produce marginal linking spines, also observed in two other, genera separated from Navicula sensu lato, i.e. Diadesmis and Luticola. However, both these genera differ significantly from Navigiolum in all other respects.

Within the "reservoir" of Navicula sensu lato only one established species, Navicula canoris Hohn et Hellerman is considered to belong to Navigiolum. It was described from Canada (HoHN \& Hellerman 1963) but occurs occasionally in Europe, for instance also in Sardinian rock pools. Whether the populations on both continents, are conspecific is, however, open to question (see LANGE-BERTALOT 2001 under Navicula exiliformis REICHARDT.

\section{Material and Methods}

The four new taxa originate from two rock pools ("Gueltas") on silicate rocks located in central Algeria, not far from the area of the Eastern Great Erg Desert on the Plateau du Tinrhert. The water bodies are shallow pools supplied by springs and rain during the winter. One of the pools (Af-12) contained a considerable growth of vascular plants whereas the other (Af-11) was barely colonised other than by microorganisms. The samples were collected in September 1982. Physical and chemical data of the water quality were not available. The diatom assemblages indicate slightly alkaline freshwater of medium electrolyte content.

Samples for diatom analyses were treated using standard procedures, sulphuric/nitric acid mix $(1: 1 \mathrm{v} / \mathrm{v})$ and repeatedly washed in distilled water; the sediment obtained was used to prepare permanent slides with 
Naphrax high resolution mountant. Light microscopical studies were carried out with a Leitz Diaplan, equipped with a100x/1.4 Plan APO oil immersion objective. For SEM analyses, material was sputter coated with gold on stubs and observed using a Hitachi S4500, operated by Manfred Ruppel, Dept. Biology, Univesity Frankfurt a. M.

\section{Results}

Navigiolum marvanii sp. nov. (Figs 1-6; 2530).

Diagnosis differens versus Navigiolum spineum LANGE-BERTALOT et al. 2003.

Valvae elliptico-lanceolatae apicibus distincte protractis subrostratis ad rostratos (nec lanceolatae apicibus non vel parum curte protractis). Longitudo 15-17 $\mu \mathrm{m}$, latitudo 4.3-5.4 $\mu \mathrm{m}$. Raphe fere recta apparens poris centralibus punctiformiter incrassatis. Striae transapicales radiantes in media parte valvae, hic 16-18 in $10 \mu \mathrm{m}$ sed distincte convergentes sub apices, ibi 20-21 in $10 \mu \mathrm{m}$. Aspectus ultramicroscopicus externus internusque vide figurae 25-30. Areolae plerumque biseriatae foraminibus externe fortiter curvatis et aperturis interne aliquid minus curvatis in alveolis sitis. Externe facies valvae constanter ornata angustis regulis apicalibus inter series areolarum etiam in area axiali sitis (nec cum facie glabra). Externa centralia raphis cum poris centralibus valde dilatatis et ad latus primum hamatis (nec simpliciter dilatatis). Ad marginem valvarum spinae circiter triangulatae sitae inter series areolarum.

Typus: Praep. Af-11 in coll. Lange-Bertalot (FR)

Locus typicus: Guelta Tin Terirt, Plateau du Tinrhert, eastern central Algeria.

This taxon is dedicated to our colleague Dr. PETR MARVAN on the occasion of his 80th birthday.

Valves elliptic-lanceolate, ends distinctly protracted subrostrate to rostrate. Length 15-17 $\mu \mathrm{m}$, breadth 4.3-5.4 $\mu \mathrm{m}$. Raphe almost straightwith distinct central pores. Striae radial in the proximal part, 16-18 in $10 \mu \mathrm{m}$ becoming convergent near the ends, 20-21 in $10 \mu \mathrm{m}$. External and internal SEM views are shown in Figs 25-30. Areolae mostly biseriate with usually crescent-shaped foramina comparable to species of Gomphonema. Internally, areolae with similarly paired slits in quite deep transapical troughs. The valve face is ornamented by apical ridges between the areolae and above the unperforated axial area. Central raphe ends with conspicuously expanded central pores hooked to the primary valve side. More or less triangular spines on the virgae at the valve margin.

Distribution: In several rock pools of central and southern Algeria.

Navigiolum algeriense sp. nov. (Figs 9, 10; 3133).

Diagnosis differens versus Navigiolum sardiniense LANGe-Bertalot et al. 2003.

Valvae lanceolatae apicibus curte protractis subrostratis. Longitudo 11-12.6 $\mu \mathrm{m}$, latitudo 2.4-3.3 $\mu \mathrm{m}$. Striae transapicales $20-21$ in $10 \mu \mathrm{m}$, in media parte valvae subparallelae, distaliter modice radiantes (nec distincte radiantes omnino). Altera signa fere coincidentia quoad aspectum in microscopio photonico. Verum tamen ambae species significanter differunt quoad aspectum ultramicroscopicum externum (vide Figs 3133 et confer cum protologo $N$. sardiniense in figuris ibi 24: 11-16). Superficies valvarum in $N$. sardiniense se praestat glaberrima sed in $N$. algeriense constanter ornata regulis apicalibus inter series areolarum. Spinae marginales in speciebus ambabus vacant.

Typus: Praep. Af-11 in coll. Lange-Bertalot (FR)

Locus typicus: Guelta Tin Terirt, Plateau du Tinrhert, eastern central Algeria.

Valves lanceolate with shortly protracted subrostrate ends. Length 11-12.6 $\mu \mathrm{m}$, breadth 2.4-3.3 $\mu \mathrm{m}$. Striae 20-21 in $10 \mu \mathrm{m}$ subparallel in the middle of the valves becoming moderately radial near the ends. Raphe filiform, slightly curved with rather widely spaced central pores appearing slightly deflected to the primary side of the valve. SEM, see Figs 31-33. Deflection to the proximal raphe ends becomes clearly visible. Apical ridges occur consistently on the external valve face between the series of areolae but different from the pattern of $N$. marvanii whereas valve faces of all other taxa of Navigiolum appear smooth. Marginal spines are lacking.

Distribution: observed at the type locality in only 

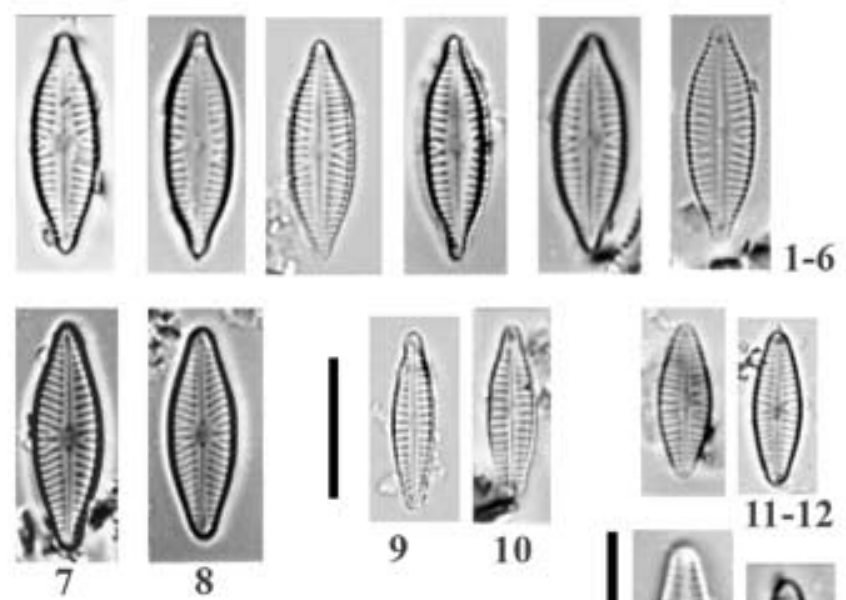

10
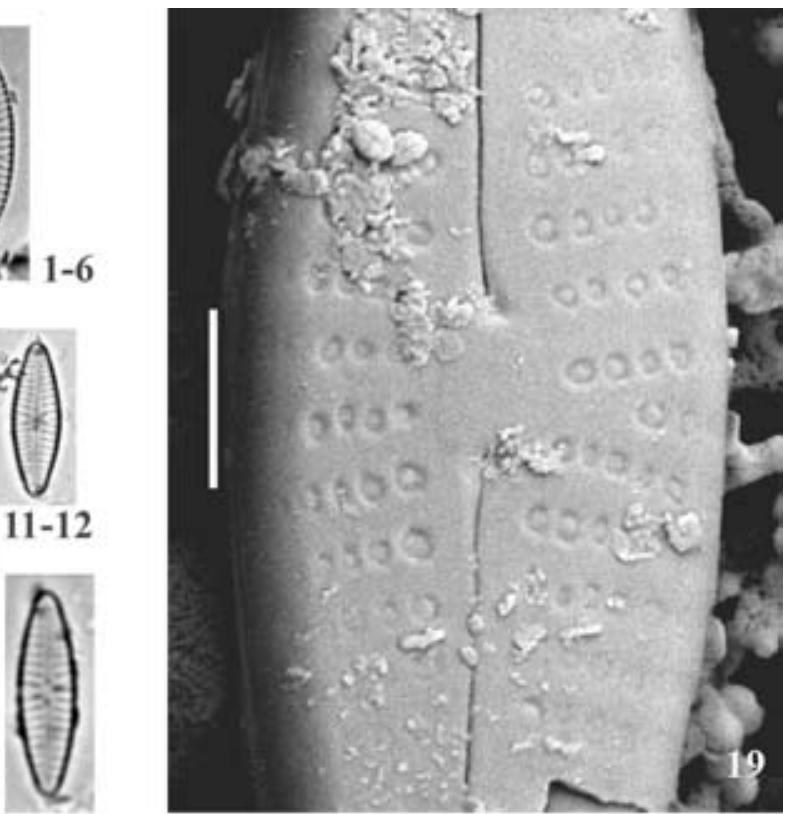

$13-16$
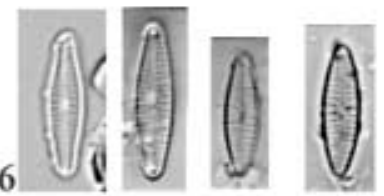

$17-18$
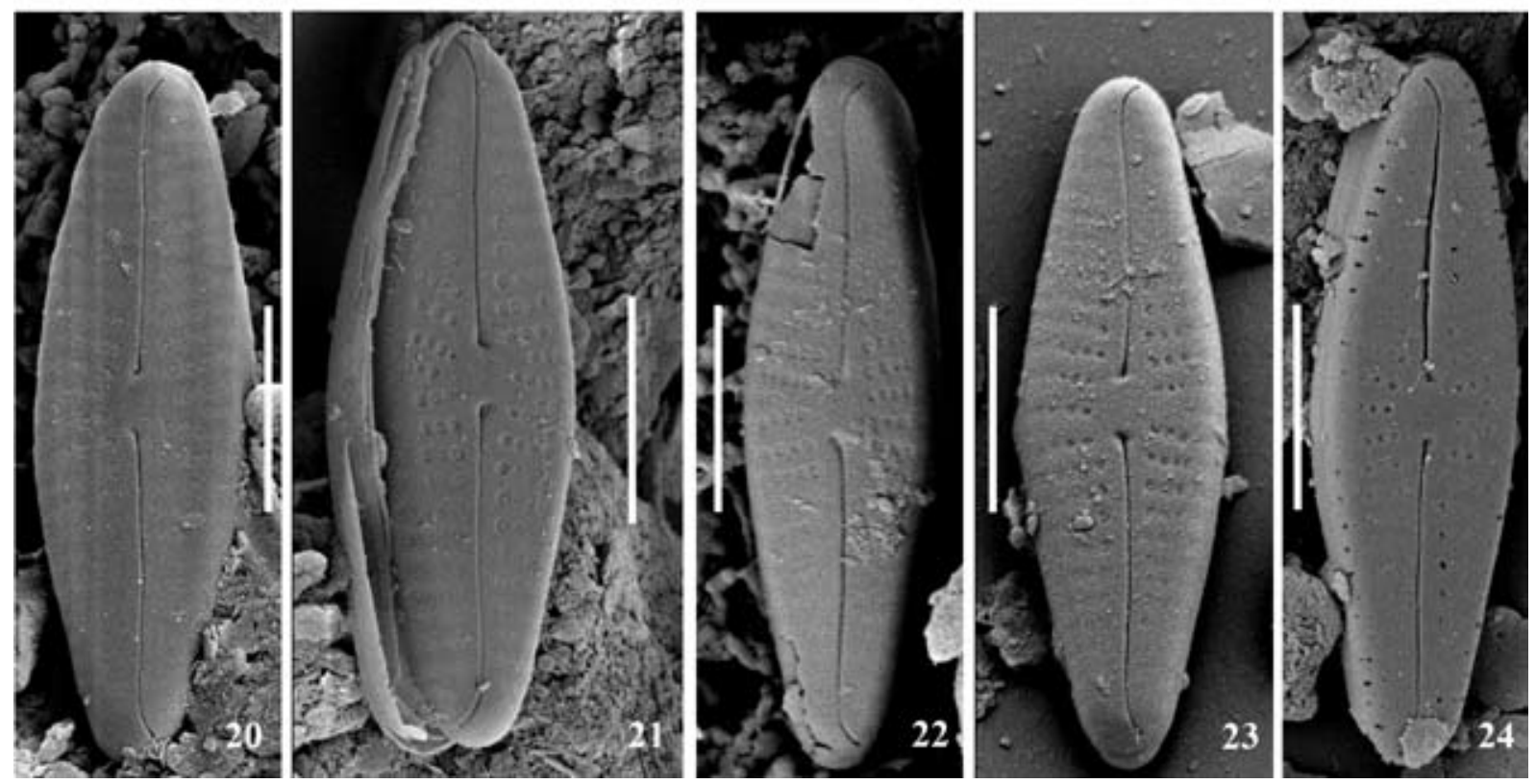

Figs 1-6. Navigiolum marvanii sp.nov.: LM observed specimens. Scale bars for all LM figures10 $\mu \mathrm{m}$. Figs 7-8. Navigiolum canoris (Hohn et Hellerman) Lange-Bertalot. LM. Figs 9-10. Navigiolum algeriense sp. nov. LM. Figs 11-12: Navigiolum simplex sp. nov. LM. Figs 13-18. Navigiolum densistriatum sp. nov. LM. Figs 19-24. Navigiolum densistriatum sp. nov. SEM. External valve views, showing the slightly sigmoid curved raphe. Note uniseriate striae composed by areolae occluded (Fig. 19). Scale bars $1 \mu \mathrm{m}$ (Fig. 19); $3 \mu \mathrm{m}$ (Figs 20-24).

one of two neighbouring rock pools.

Navigiolum simplex sp. nov. (Figs 11, 12; 34, 35).

Diagnosis differens versus Navigiolum canoris (Hohn et Hellerman) Lange-Bertalot 2003

Valvaerombico-lanceolatae apicibus non protractis simpliciter acute rotundatis. Longitudo 10-10.8 $\mu \mathrm{m}$ (nec 13-15 $\mu \mathrm{m}$ ), latitudo 3.3-3.7 $\mu \mathrm{m}$ (nec 3.8-4.8 $\mu \mathrm{m}$ ). Raphe recta filiformis. Area axialis angustissima, area centralis minima indistincta.
Striae transapicales $20-21$ in $10 \mu \mathrm{m}$ modice (nec fortiter) radiantes omnino in media parte cum una singula stria abbreviata (non alternantibus curtis longisque vide Figs 11, 12 comparate Figs 7, 8). Aspectus ultramicroscopicus externus vide Figs 34, 35. Raphe minime (nec distinctissime) curvata ad polos. Foramina areolarum occlusa externe semicircularia vel rectangulata plerumque uniseriata sed partim biseriata ut communiter in genere. Spinae ad margines etiam regulae longitudinales super faciem valvae vacant. 

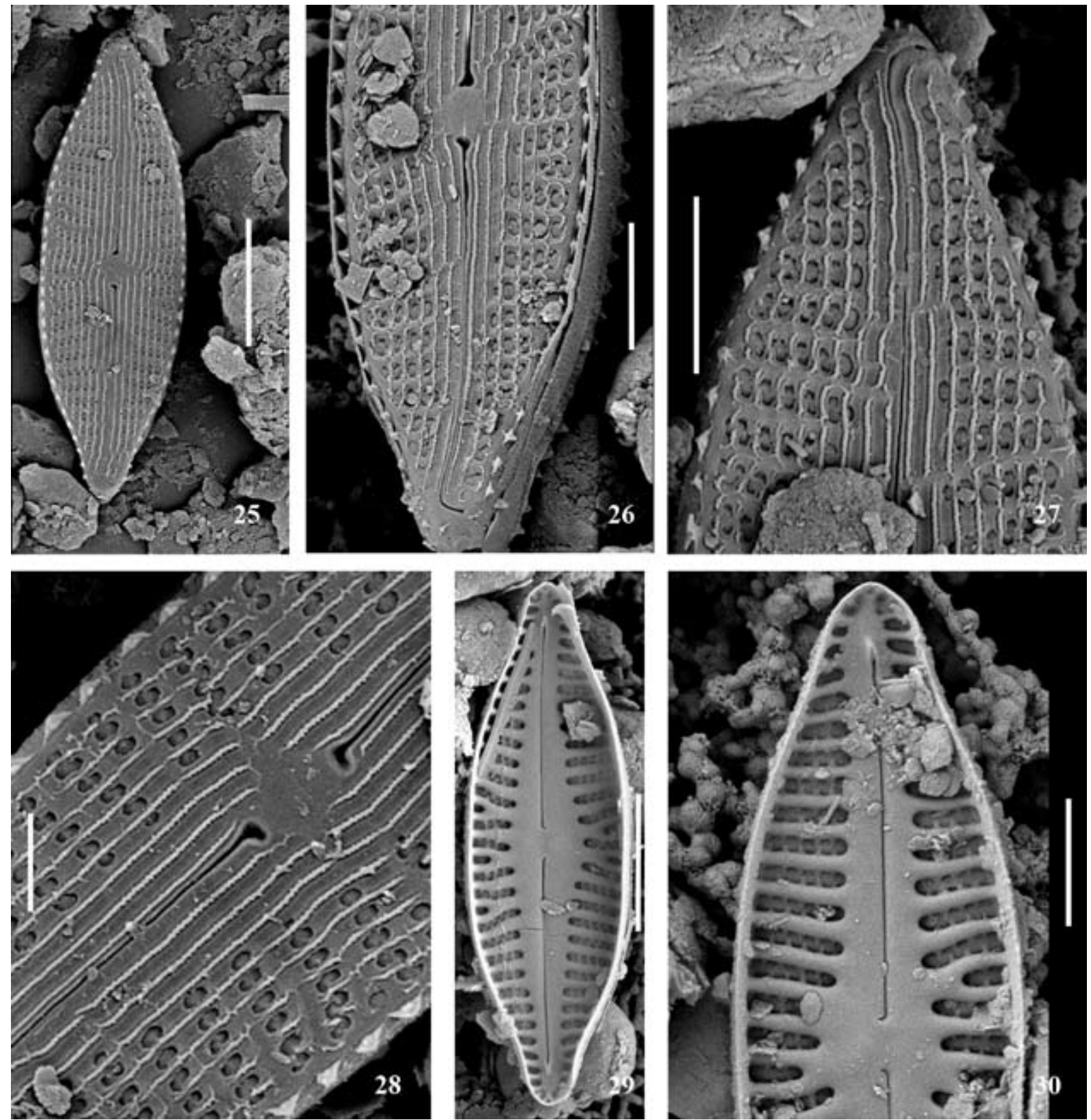

Figs 25-30. Navigiolum marvanii sp. nov. SEM. (25-28) external valve views ornamented by apical ridges, see expanded central pores and marginal triangular spines (Fig. 28); (29-30) internal valve views. See areolae lying in transapical troughs (Fig. 30). Scale bars $5 \mu \mathrm{m}$ (Fig. 25); $2 \mu \mathrm{m}$ (Figs 26, 27, 30); $1 \mu \mathrm{m}$ (Fig. 28); $4 \mu \mathrm{m}$ (Fig. 29).

Navigiolum sardiniense differt apicibus anguste protractis et proprie area axiali lanceolata itaque striis transapicalibus abbreviatis et area centrali non separata. $N$. densistriatum differt valvis distincte angustioribus et striis densius sitis inter se.

Typus: Praep. Af-12 in coll. LANGe-Bertalot (FR).

Locus typicus: Guelta no. 2, Tin Terirt, Plateau du Tinrhert, eastern central Algeria.
Differential diagnosis compared to Navigiolum canoris (Hohn et Hellerman) Lange-Bertalot 2003 (see Figs 7, 8, 36).

Valves rhombic-lanceolate, with acutely rounded (not protracted) apices. Length 10-10.8 $\mu \mathrm{m}$ (not 13-15 $\mu \mathrm{m})$, breadth 3.3-3.7 $\mu \mathrm{m}$ (not 3.8-4.8 $\mu \mathrm{m})$. Raphe straight, filiform. Axial area very narrow; central area very small with indistinct outline. Transapical striae $20-21$ in $10 \mu \mathrm{m}$, moderately (not strongly) radial throughout. A single stria in the centre may be shortened (not several striae alternately shorter and longer cf. Figs 7, 8). 

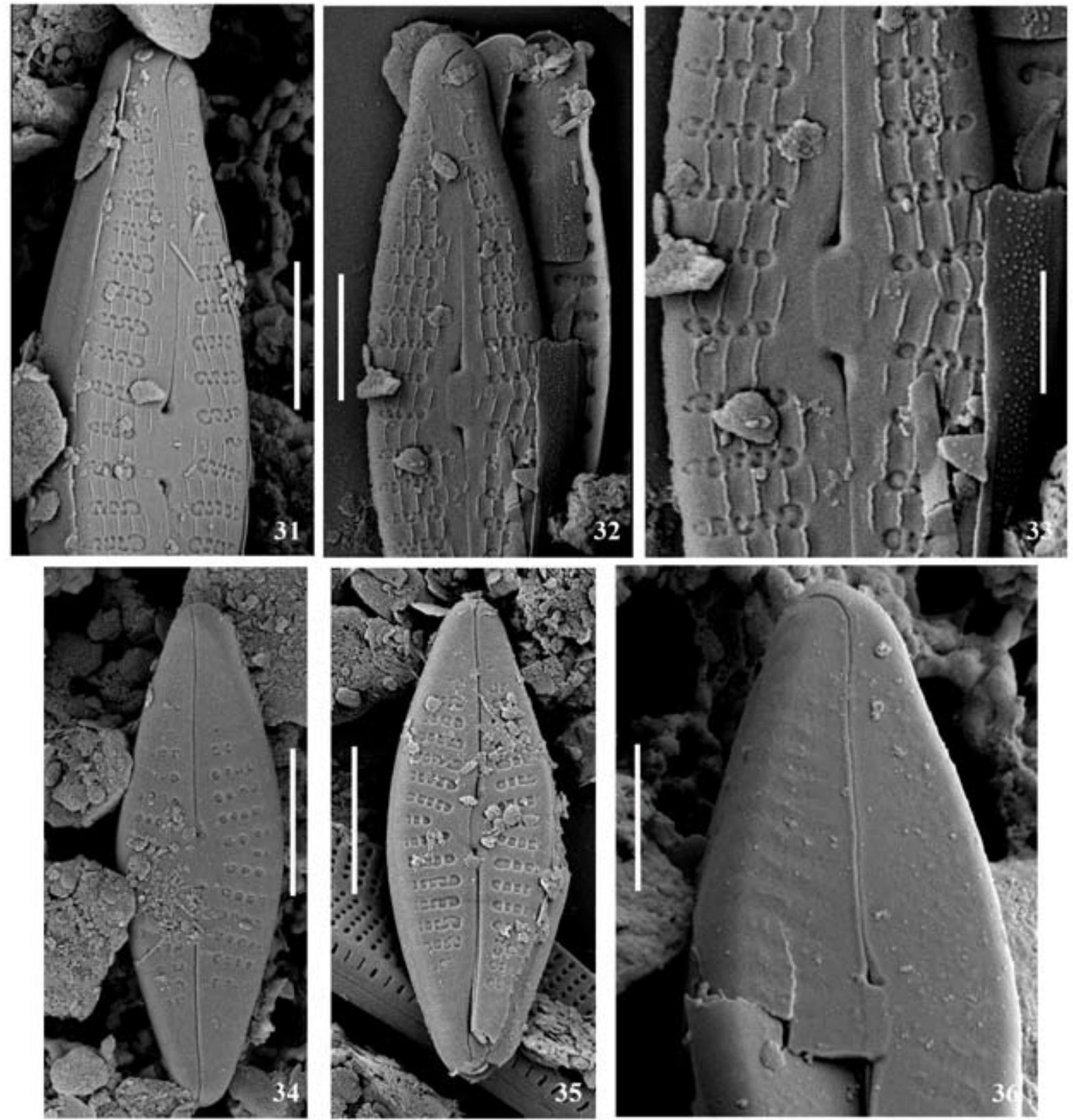

Figs 31-33. Navigiolum algeriense sp. nov. SEM. External valve views. Note apical ridges and lacking of spines. Scale bars $2 \mu \mathrm{m}$ (Figs 31, 32); $1 \mu \mathrm{m}$ (Fig. 33). Figs 34-35. Navigiolum simplex sp. nov. SEM. External valve views. The raphe slit quite straight. Scale bars $3 \mu \mathrm{m}$. Fig. 36. Navigiolum canoris (Hohn et Hellerman) Lange-Bertalot SEM. External valve view. A detail of areolae completely masked by occluding membranes. Scale bar $2 \mu \mathrm{m}$.

SEM, external view in Figs 34, 35. Raphe slit only very slightly (not strongly) curved at the apices. Foramina of the areolae, as commonly in this genus, crescent-like, mostly uniseriate but partly becoming biseriate. The distal areolae remain masked, by thin closing membranes, compare with $N$. canoris (Fig. 36) where the entire areolation is masked if uncorroded. Marginal spines and apically orientated ridges on the valve face are lacking.

Navigiolum canoris is not associated with
$N$. simplex but occurs in another Guelta (near Tamrit, Tassili, South Algeria). It differs from $N$. sardiniense in not having narrowly protracted ends nor a broader, lanceolate axial area caused by shortened striae, a central area is not separated Navigiolum densistriatum is best distinguished by consistently narrower valves and denser spaced striae (see elsewhere). Navigiolum (? nov.) spec. from Sardinia (Lange-Bertalot et al. 2003, Figs 26: 6-8) possesses similar valve outlines and size but differs in lower stria density, 16-18 in $10 \mu \mathrm{m}$. 
Distribution: N. simplex was only found in two closely situated rock pools. It is the rarest of the five species observed in Algerian Gueltas both in frequency and abundance.

Navigiolum densistriatum sp. nov. (Figs 13-24). Valvae anguste-lanceolatae vel ellipticolanceolatae apicibus nonnumquam parum protractis sive simpliciter cuneatim rotundatis. Longitudo 8.7-11.5 $\mu \mathrm{m}$, latitudo 2.5-3.3 sed plerumque sub $3 \mu \mathrm{m}$. Raphe filiformis difficulter aspectabilis distaliter poris centralibus fere dense sitis inter se. Area axialis angustissima, area centralis parva indistincta. Striae transapicales modice radiantes et subparallelae ad apices versus, $25-28$ in $10 \mu \mathrm{m}$. Aspectus ultramicroscopicus externus vide Figs 19-24. Rami raphis cum extremis centralibus terminalibusque leviter curvati sigmoidei. Foramina areolarum occlusa externe circiter circularia vel semicircularia uniseriata in mediis partibus valvae indistincte formata in partibus distalibus. Spinae marginales et regulae longitudinales super faciem valvae vacant. Omnes alterae species generis adhuc cognitae differunt dimensionibus maioribus atque striis transapicalibus distantius sitis inter se.

Typus: Praep. Af-11 in coll. Lange-Bertalot (FR)

Locus typicus: Guelta Tin Terirt, Plateau du Tinrhert, eastern central Algeria.

Valves narrow-lanceolate to elliptical-lanceolate, ends either very slightly protracted or cuneately rounded. Length $8.7-11.5 \mu \mathrm{m}$, breadth $2.5-3.3 \mu \mathrm{m}$ usually less than $3 \mu \mathrm{m}$. Raphe filiform, difficult to resolve in distal parts, central pores rather closely spaced. Axial area very narrow, central area small, indistinctly defined. Striae moderately radial becoming subparalled towards the ends, 25-28 in $10 \mu \mathrm{m}$. SEM, external view, see Figs 19-24. Raphe branches appear slightly curved sigmoid including the deflected central ends and terminal fissures. Foramina of the areolae occluded externally appearing masked in the distal parts if uncorroded, in the central part of the valve approximately circular or semicircular and uniseriate. Marginal spines and apically orientated silicate ridges lacking. All more or less similar taxa are distinguished in LM by lower dimensions and less striae in $10 \mu \mathrm{m}$.

Distribution: found in fairly high abundance in the three Gueltas, two in the Plateau du Tinhert and one in the Ahaggar Mountains in South Algeria. Never observed in Europe, also not in Sardinia under comparable ecological conditions. On the other hand, the comparatively very small cells might have been overlooked or neglected in other Algerian habitats under investigation formerly.

\section{Discussion}

Navigiolum was described as a polythetic genus that shares many morphological features with Mayamaea LANGE-Bertalot 1997 (see LANGEBERTALOT 2001) which is apparently the only one closer related genus among established genera. Both possess exclusively species with comparatively small to very small cell dimensions. Valves were found to be not longer than 11-17 $\mu \mathrm{m}$ and not broader than 3.3-6 $\mu \mathrm{m}$ in eight so far known taxa of Navigiolum. Mayamaea, covering more than 20 taxa, was measured being 6-16 $\mu \mathrm{m}$ long and $2-7 \mu \mathrm{m}$ broad.

The raphe system appears conforming in external and internal view. The areolae pattern, similar in general, is masked by closing membranes lying flush with the valve surface. These thin membranes disappear easily by corrosion after mineral acid treatment. Distinguishing features of Navigiolum are crescent-like to reniform areola foramina that become subdivided biseriate comma-like in most of the species whilst being roughly circular in Mayamaea. At least three of eight species possess prominent linking spines regularly arranged on the junction between valve face and mantle; in situ they form ribbon-like aggregates. Two of the species described here as new possess apically arranged filiform ridges on the valve faces. Moreover, the valve shape is generally lanceolate and not elliptical. The ends are facultatively protracted rostrate but always acutely rounded, never bluntly rounded compared to Mayamaea.

Investigating comparable rock pools in various regions of central and southern Algeria several unknown populations of Navigiolum could be observed associated in similar diatom assemblages as in Sardinia. At first glance (LM) they look roughly like the presumably endemic taxa from Sardinia. Comparison of the valve micromorphology in detail however, reveals significant differences. None of the four Algerian populations coincides with the Sardinian 
specimens and hence are described here as new to science (see Observations). On the other hand, numerous taxa in other genera recently described from such habitats in Sardinia (LANGE-BERTALOT et al. 2003) have been found again in Algeria. They seem to be restricted to this rather unusual type of water body in a hot, dry summer climate with high winter-spring precipitation, which results in periodically high and low water levels in shallow, discharge-less depressions on non-calcareous bedrocks.

Such a climatic region encompasses the southern Mediterranean and northern African coasts. Thus the rock pool diatom flora represents both endemic elements in a wider sense based on special ecological conditions and endemics with narrower limits. With eight to ten rather closely related but taxonomically separated populations in this area the genus Navigiolum is representative of the latter.

BAUDRIMONT (1974) enumerated 417 diatom taxa from Algeria. Based on his own investigations on fossil deposits, and on the extant flora of freshwater and brackish water habitats he found 206 taxa. None resembles any of the known Navigiolum species. Most of the cited species are typical of high conductivity, eutrophic waters. To date, Navigiolum species have only been found in oligosaprobic and oligohalobious waters.

\section{References}

BAUDRIMOnT, R. (1974): Recherches sur les Diatomées des eaux Continentales de l'Algerie: Ecologie et Paleoécologie. - Soc. Hist. Nat. Afrique du Nord, Mem., 12. Nlle Sér.

Hohn, M.H. \& Hellerman, J. (1963): The taxonomy and structure of diatom populations from three eastern North American rivers using three sampling methods. - Transact. American Microscop. Soc. 80: 250-329.

Lange-Bertalot, H. (2001): Navicula sensu stricto, 10 genera separated from Navicula sensu stricto, Frustulia. Diatoms of Europe vol. II: A.R.G. Gantner Ruggell Liechtenstein.

Lange-Bertalot, H., Cavacini, P., Tagliaventi, N. \& Alfinito, S. (2003): Diatoms of Sardinia. Rare and 76 new species in rock pools and other ephemeral waters. Iconographia Diatomologica, 12. A.R.G. Gantner Ruggell Liechtenstein.

(C) Czech Phycological Society

Received February 22, 2009

Accepted May 5, 2009 